\title{
Inline Milk Lactose Concentration as Biomarker of the Health Status and Reproductive Success in Dairy Cows
}

\author{
Mindaugas Televičius ${ }^{1, *}$, Vida Juozaitiene ${ }^{2}$, Dovilè Malašauskienè ${ }^{1}$, Ramunas Antanaitis ${ }^{1}{ }^{1}$, \\ Arūnas Rutkauskas ${ }^{1}$, Mingaudas Urbutis ${ }^{1}$ and Walter Baumgartner ${ }^{3}$ (D) \\ 1 Large Animal Clinic, Veterinary Academy, Lithuanian University of Health Sciences, Tilžès 18, \\ LT-47181 Kaunas, Lithuania; dovile.malasauskiene@1smuni.lt (D.M.); ramunas.antanaitis@lsmuni.lt (R.A.); \\ arunas.rutkauskas@lsmuni.lt (A.R.); mingaudas.urbutis@lsmuni.lt (M.U.) \\ 2 Department of Animal Breeding, Veterinary Academy, Lithuanian University of Health Sciences, Tilžès 18, \\ LT-47181 Kaunas, Lithuania; vida.juozaitiene@lsmuni.lt \\ 3 University Clinic for Ruminants, University of Veterinary Medicine, Veterinaerplatz 1, \\ A-1210 Vienna, Austria; walter.baumgartner@vetmeduni.ac.at \\ * Correspondence: mindaugas.televicius@lsmuni.lt; Tel.: +37060134279
}

check for updates

Citation: Televičius, M.; Juozaitiene, V.; Malašauskienė, D.; Antanaitis, R.; Rutkauskas, A.; Urbutis, M.; Baumgartner, W. Inline Milk Lactose Concentration as Biomarker of the Health Status and Reproductive Success in Dairy Cows. Agriculture 2021, 11, 38. https://doi.org/ 10.3390 /agriculture11010038

Received: 6 December 2020

Accepted: 5 January 2021

Published: 8 January 2021

Publisher's Note: MDPI stays neutral with regard to jurisdictional clai$\mathrm{ms}$ in published maps and institutional affiliations.

Copyright: (C) 2021 by the authors. Licensee MDPI, Basel, Switzerland. This article is an open access article distributed under the terms and conditions of the Creative Commons Attribution (CC BY) license (https:// creativecommons.org/licenses/by/ $4.0 /)$.

\begin{abstract}
In this study, cow reticulorumen content $\mathrm{pH}$ and temperature together with the activity were registered using smaXtec boluses, specially designed for animal care. Body weight, rumination time, milk fat/protein ratio, milk yield, milk lactose, milk electrical conductivity, milk somatic cell count and consumption of concentrated feed were registered by Lely Astronaut ${ }^{\circledR}$ A3 milking robots. The cows in this study were assigned into two groups according to the milk lactose concentration: group $1-$ milk lactose $<4.70 \%(n=20)$, group $2-$ milk lactose $\geq 4.70 \%(n=15)$. The following cows were further classified according to milk fat and protein ratio: $\mathrm{F} / \mathrm{P}<1.2$ (class 1), $\mathrm{F} / \mathrm{P}=1.2$ (class 2) and $\mathrm{F} / \mathrm{P}>1.2$ (class 3 ). According to our results, we can conclude that inline registered milk lactose concentration can be used to indicate the health status and reproductive success of fresh dairy cows. Cows with an increased lactose concentration $(\geq 4.70 \%)$ showed more activity $(54.47 \%)$ and had less risk of mastitis (determined by lower milk electrical conductivity (EC) and somatic cell counts (SCC)) and metabolic disorders, determined by milk F/P. A higher glucose concentration was also apparent in the cows with higher lactose concentration. Registered lower levels of milk lactose can be used for early identification of metabolic disorders and mastitis (set at milk SCC $\geq 100$ thousand/mL). Lactose levels in cows' milk were positively associated with their reproductive success.
\end{abstract}

Keywords: milk lactose; dairy cows; automatic milking system; smart farming

\section{Introduction}

Precision livestock farming (PLF) is defined as the use of real-time monitoring technologies to manage the smallest production unit-in other words, approaching an individual animal with the help of sensors. PLF technology has tremendous potential in creating added value for many stakeholders, mostly as a management tool fit for farmers, providing a better possibility to improve animal welfare, efficiency and health and to diminish the environmental impact [1]. One part of PLF is an automatic milking system (AMS). AMSs and automatic milking rotary (AMR) parlors are the most recent technological innovations, providing more frequent milking events with a decreased need for human labor. To date, scientific research has looked into various aspects of AMS technology and its effect on herd health, milk quality, welfare, management and behavior [2]. Previous management and milking systems were not able to gather and provide detailed information about each individual cow, unlike nowadays' used automatic sensors, which amass data about udder health, reproductive status, milk production, feed intake and body weight [3]. As a result, this allows for a more detailed monitoring of an individual animal's health and production status. The milking robot is a classic PLF application and one of the types of AMSs: in this 
situation, one single quarter of an udder is considered the smallest manageable production unit [4]. At the beginning of this century, a simulation optimization based on animal behavior was developed for robotic milking farms [5]. In robotic milking, the following parameters are usually recorded: milk lactose, milk content, milk protein, milk fat, electrical conductivity and somatic cell count. Milk lactose is one of the major bovine milk solids, and its concentration in milk and synthesis are affected greatly by udder health and the cow's metabolism and energy balance. Since milk lactose is related to several biological and physiological factors, information on milk lactose in the literature is provided considering its chemical properties, heritability and genetic associations with health traits that play a role in breeding [6]. Several studies have delved into the relationship of lactose content with fertility [7]. Some studies state that lactose percentage seemed a good predictor of days to first and second postpartum ovulation [8]. Higher percentage of lactose was associated with increased pregnancy rate [9] and an increased lactose concentration in the first 8 weeks postpartum correlated with early luteal response in second-parity cows [10]. Not only that, but the fat to lactose ratio has been described as an indicator of subclinical and clinical ketosis [11] and provided the best estimation of energy balance [12]. It has been reported that milk lactose concentrations decrease and somatic cell counts (SCC) increase during clinical and subclinical mastitis [13]. Thus, the monitoring of lactose concentrations in milk could be used as an indicator of mastitis, as a clear decrease is noted during inflammation [13]. Monitoring the lactose levels may help in the quality control and management of farms, helping in the identification of low-quality milk [14] and energy inefficiencies [15,16]. In the literature, we found very little information about the relation between inline milk lactose concentration and health as well as reproduction statuses in dairy cows. According to this, the aim of this current study was to evaluate the relationship of an inline registered milk lactose concentration with biomarkers from an AMS and to determine the ability to use milk lactose concentration as an indicator of health status and reproduction success of fresh dairy cows.

\section{Materials and Methods}

\subsection{Location, Animals and Experimental Design}

The research was carried out in accordance with the provisions of the Law on Animal Welfare and Protection of the Republic of Lithuania (Official Gazette Valstybes žinios, 1997, No. 108-2728; 2012, No. 122-6126). The 22 September Directive 2010/63/EU of the European Parliament and of the Council on the protection of animals used for scientific purposes (OJ 2010 L 276, p. 33) was adhered to, as well as adhering to the European Convention for the protection of vertebrate animals used for experimental and other scientific purposes (Official Journal 2007, No 49)-1883, No. 49-1884). The study approval number is PK016965.

The study was carried out during the summer period from 2019.09.01-2019.10.01. The experiment took place on a dairy farm in the Kaunas region, Lithuania 54.9753923, 23.7662303. A total of 35 Lithuanian Black and White dairy cows (1-30 days postpartum) having had two or more lactations (on average $2.9 \pm 0.13$ lactations) and being clinically healthy were included in the study. Selected cows were tested in two stages: A (1-30 d.p.p.) and B (30 d.p.p.- until insemination). The average BW of all cows was $649.14 \pm 18.92 \mathrm{~kg}$, and the level of milk SCC was less than 200 thousand $/ \mathrm{mL}$. The cows were housed in a loose system and fed total mixed ration (TMR) twice daily, at 06:00 $\mathrm{h}$ and 18:00 h. A basic total mixed ration was fed to high-producing, multiparous cows that consisted primarily of $50 \%$ grain concentrate mash, alfalfa hay (13\% protein), $10 \%$ grass silage, sugar beet pulp silage, $30 \%$ corn silage, $4 \%$ grass hay wheat straw and compound feed. The feed ration was balanced to fit the energy and nutrient requirements of a 550-650 kg Holstein cow producing, on average, $35 \mathrm{~kg} /$ day of milk throughout the experimental period. Chemical composition of the ration was as follows: $47.8 \%$ dry matter (DM); 29.02 (\% of DM) neutral detergent fiber; 37.8 ( $\%$ of DM) crude protein; acid detergent fiber non-fiber carbohydrates 
17.5 (\% of DM); 1.8 (Mcal $/ \mathrm{kg}$ ) net energy for lactation. Two $\mathrm{kg} / \mathrm{d}$ of concentrates were fed to cows by the milking robot. The average cow milk production was $35 \mathrm{~kg} / \mathrm{d}$.

\subsection{Measurements}

The temperature, $\mathrm{pH}$ of the contents of cow reticulorumen and cow activity were registered using specific smaXtec boluses, specially manufactured for animal care. SmaXtec animal care technology ${ }^{\circledR}$ enables the continuous real-time monitoring of various data such as ruminal $\mathrm{pH}$ and temperature. According to the instructions provided by the manufacturer, the boluses were inserted into the reticulorumen of the studied cows using a specific tool. Specific antennas (smaXtec animal care technology ${ }^{\circledR}$ ) were used to receive the data from the indwelling boluses (smaXtec animal care GmbH, Graz, Austria). The system was controlled by a microprocessor. The data for $\mathrm{pH}$ and temperature changes were collected using an analogue-to-digital converter (A/D converter) and stored in an external memory chip. Due to its small dimensions (a length of $12 \mathrm{~cm}$, width: $3.5 \mathrm{~cm}$, weight: $210 \mathrm{~g}$ ), this indwelling system can be easily orally administered to an adult cow and its special build makes it shock-proof and resistant to rumen fluid. At the beginning of the experiment, the $\mathrm{pH}$ probes had to be calibrated using $\mathrm{pH} 4$ and $\mathrm{pH} 7$ buffer solutions. The data were registered every 10 min daily. All data were collected and displayed by smaXtec messenger ${ }^{\circledR}$ computer software.

The cows were milked with free-traffic Lely Astronaut ${ }^{\circledR}$ A3 milking robots. Parameters such as rumination time (RT), milk yield (MY), body weight (BW), milk lactose (L), milk somatic cell count (SCC), milk electrical conductivity (EC) of all quarters of the udders (front left (FL), front right (FR), rear left (RL), rear right (RR)), milk fat/protein ratio (F/P) and consumption of concentrates were registered with the help of Lely Astronaut ${ }^{\circledR}$ A3 milking robots each time the cow was being milked.

Cows were inseminated upon detection of one or more behavioral and physical signs of estrus such as: increased activity, jumping on other cows, transparent mucus on the root of the tail, congestion of vulval mucous membrane and uterine tone, and according to the information of the automatic milking system. Cow pregnancy was examined using an ultrasound "Easy scan" (IMV imaging, Scotland) 30-35 days after insemination.

From 1500 cows, according to the level of lactose in milk, cows were assigned into two groups: group 1 -milk lactose $<4.70 \%(n=20)$, group 2 -milk lactose $\geq 4.70 \%(n=15)$.

Data of cows were also grouped by milk fat and protein ratio: $\mathrm{F} / \mathrm{P}<1.2$ (class 1), F/P $=1.2($ class 2$)$ and $\mathrm{F} / \mathrm{P}>1.2($ class 3$)$.

\subsection{Data Analysis and Statistics}

The statistical analysis of data was performed using the SPSS 25.0 (SPSS Inc., Chicago, IL, USA) program package. Mean values recorded by milking robots (RT; BW; MY; F/P; L; SCC; EC), averaged from 30 days after calving until insemination, were used in the study. Normal distributions were assessed using the Kolmogorov-Smirnov test, using descriptive statistics. The results were provided as the mean \pm standard error of the mean $(\mathrm{M} \pm \mathrm{SE})$. Student's $t$-test was used to analyze the differences in mean values of normal distributed variables. A probability of less than 0.05 was considered reliable $(P<0.05)$.

The Pearson correlation $(r)$ was determined to define the linear relationship of milk lactose with reticulorumen parameters such as $\mathrm{pH}$ and temperature $(\mathrm{T})$ as well as biomarkers from the AMS: milk yield (MY), milk fat, milk protein and milk fat and protein ratio $(\mathrm{F} / \mathrm{P})$, electrical conductivity of milk (EC) at udder quarters level (right front, left front, right rear, left rear), activity of cows, consumption of concentrates (CC) and rumination time (RT). The relationship between the SCC class of milk (SCC $<100$ thousand $/ \mathrm{mL}$ or SCC $\geq 100$ thousand $/ \mathrm{mL}$ ) and a group of cows by milk lactose level was evaluated using Pearson's $\chi 2$ test.

A binary logistic regression method was executed using milk lactose level as a dependent variable to project the relationship between SCC and F/P levels in cows' milk. Estimates were used to calculate odds ratios (ORs). 


\section{Results}

The average productivity of cows was $40.94 \pm 1.07 \mathrm{~kg}$, milk fat concentration-4.46 $\pm 0.106 \%$, milk protein $-3.66 \pm 0.034 \%$, milk lactose $-4.65 \pm 0.009 \%$, and milk fat and protein ratio-1.22 \pm 0.029 .

\subsection{The Relationship between the Level of Milk Lactose and Milk Characteristics of Cows}

The lactose content in the milk of cows was significantly positively related to the content of milk protein $(r=0.436 ; P<0.05)$ and negatively correlated with the EC of milk $(r=-0.695-0.993 ; P<0.001)$. The correlations of milk lactose with MY, milk fat and F/P were slightly positive $(0.091-0.170)$ and significantly unreliable $(P>0.05)$ (Figure 1$)$.
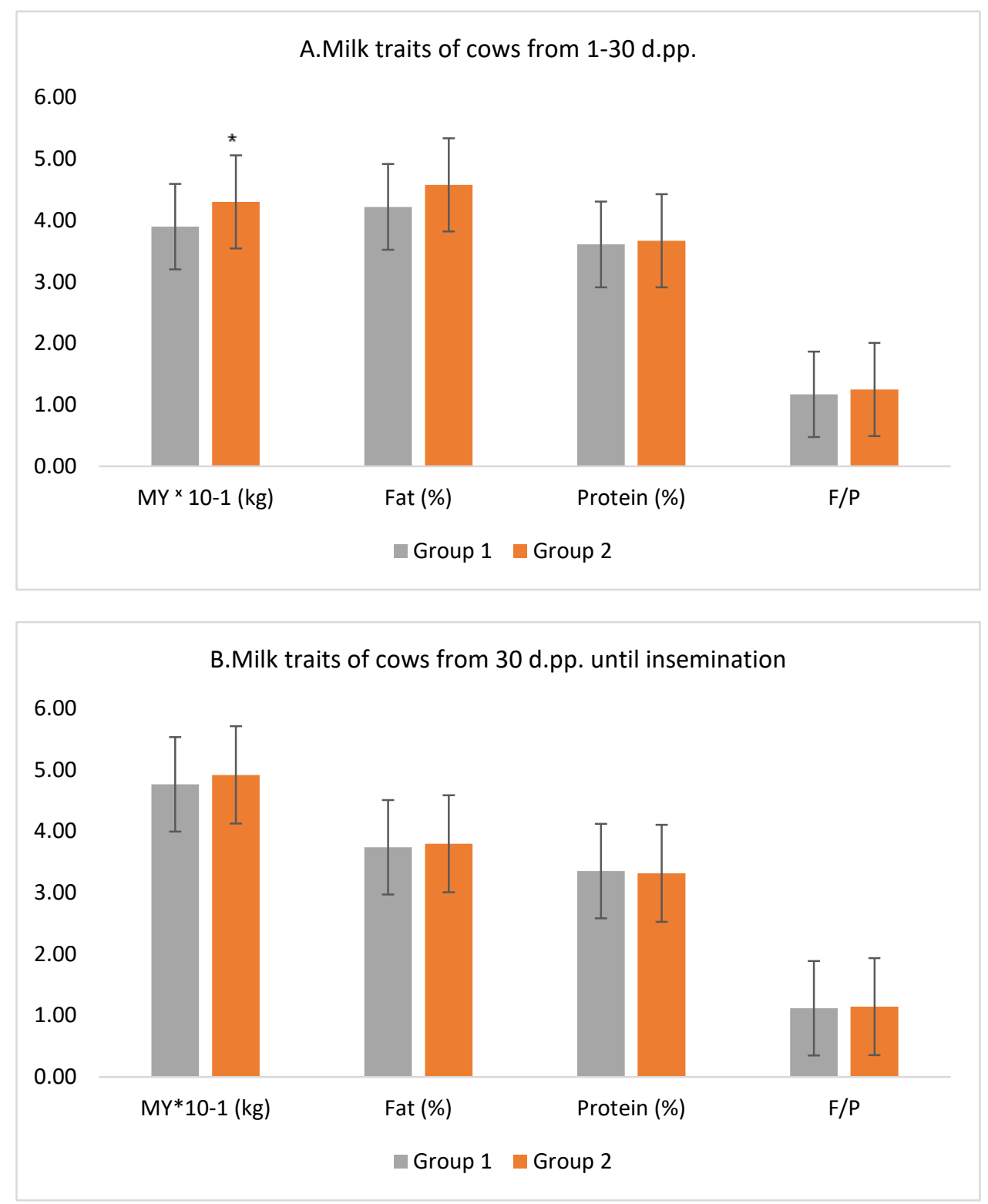

Figure 1. Milk characteristics of cows by milk lactose level. (A). 1-30.p.p., (B). From 30 d.p.p. until insemination. Group 1 -milk lactose $<4.70 \%$, Group 2 -milk lactose $\geq 4.70 \%$. MY-milk yield. F/P-milk fat/protein ratio. d.p.p-days post partum. The difference between the groups is statistically significant- ${ }^{*} P<0.005$.

Productivity in the cows of the first group was $10.26 \%$ lower, and the milk fat and protein ratio was $9.59 \%$ lower. The milk contents of the second group had less milk fat and 
protein (1.09 and 1.02 times), but the differences between the average for these indicators of milk were not significant.

The electrical conductivity level of milk in group 1 was higher in all quarters of the udders compared to cows in group 2 (Figure 2), from 5.66\% (rear right quarter) to $9.72 \%$ (front right quarter), and differences between groups in EC means of milk in all udder quarters were significant $(P<0.001)$.
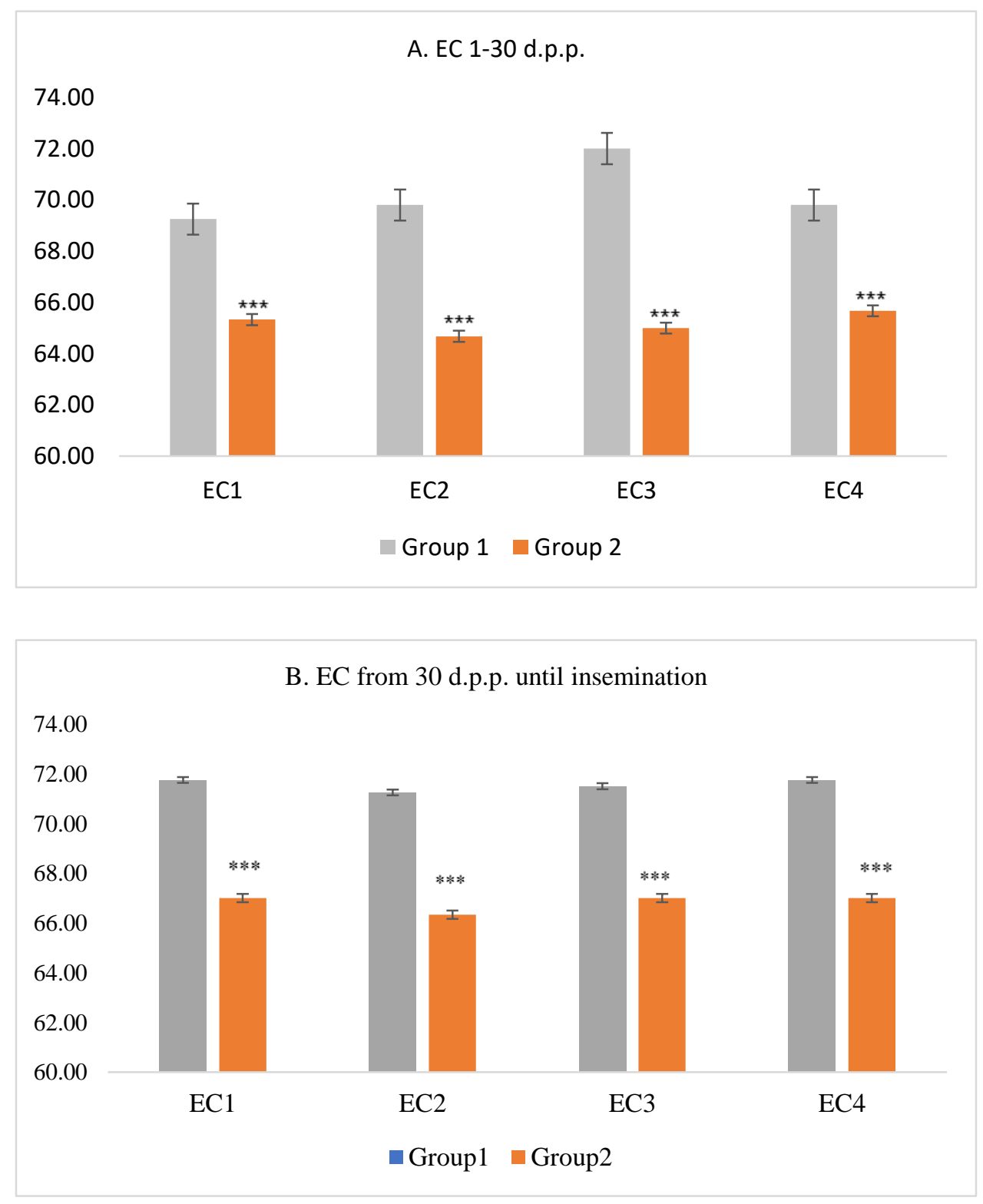

Figure 2. Electrical conductivity of cows' milk at the level of udder quarters ( $\mu \mathrm{S} / \mathrm{cm})$. (A). 1-30.p.p., (B). From 30 d.p.p. until insemination. Group 1-milk lactose $<4.70 \%$, Group 2-milk lactose $\geq 4.70 \%$. EC1—rear right, EC2-rear left, EC3-front right, EC4—front left. The difference between the groups is statistically significant— ${ }^{* *} P<0.001$.

A significant relationship between group of cows and level of SCC in milk has been estimated $(P<0.001)$. In group 1 , we found $59.52 \%$ more cows with milk SCC $\geq 100$ thousand $/ \mathrm{mL}$ (Figure 3). Odds of subclinical mastitis among cows with concentration of lactose $<4.70 \%$ are 15 -fold higher than in cows with lactose concentration above this level $(\mathrm{OR}=15.583, \mathrm{P}=0.001)$. 


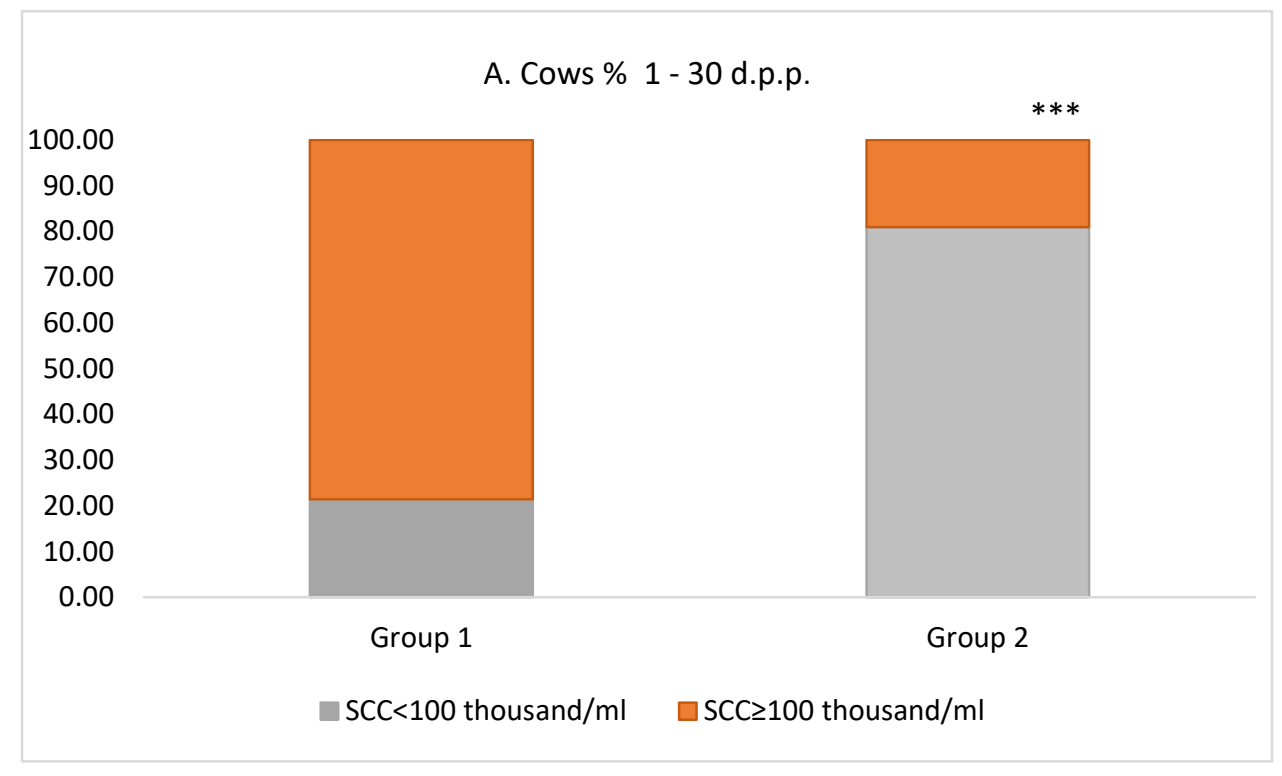

B. Cows $\% 30$ d.p.p. - until insemination

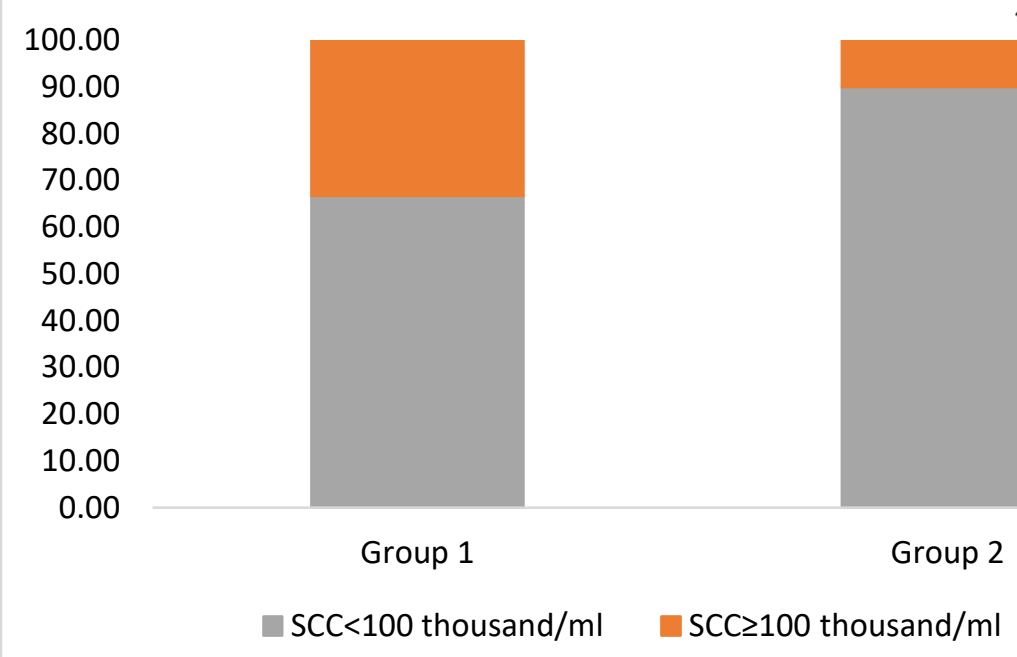

Figure 3. Relationship of milk somatic cell counts (SCC) with milk lactose level. (A). 1-30.p.p., (B). From 30 d.p.p. until insemination. Group 1-milk lactose $<4.70 \%$, Group 2 -milk lactose $\geq 4.70 \%$. SCC -milk somatic cell count. The association between group and SCC of milk is statistically significant- ${ }^{* *} P<0.01,{ }^{* * *} P<0.001$.

Cows with lactose $<4.70 \%$ in milk were also found to be more prone to the risk of subclinical acidosis or ketosis ( $\mathrm{OR}=2.00, P=0.376)$. The cows of the first group with SARA signs accounted for $33.33 \%$ more animals than the cows of the second group. We also found that in THE F/P > 1.2 class, there were $9.09 \%$ more cows of the first group, and in this class with signs of subclinical ketosis, the total number of cows of the second group was $54.55 \%$ (Figure 4 ).

From our investigation, $50 \%$ of cows in the first group had a risk of mastitis (milk SCC $\geq 100$ thousand $/ \mathrm{mL}$ ) and, at the same time,-a risk of metabolic disorders according to $\mathrm{F} / \mathrm{P}$. None of the cows in the second group had this risk of both diseases. 

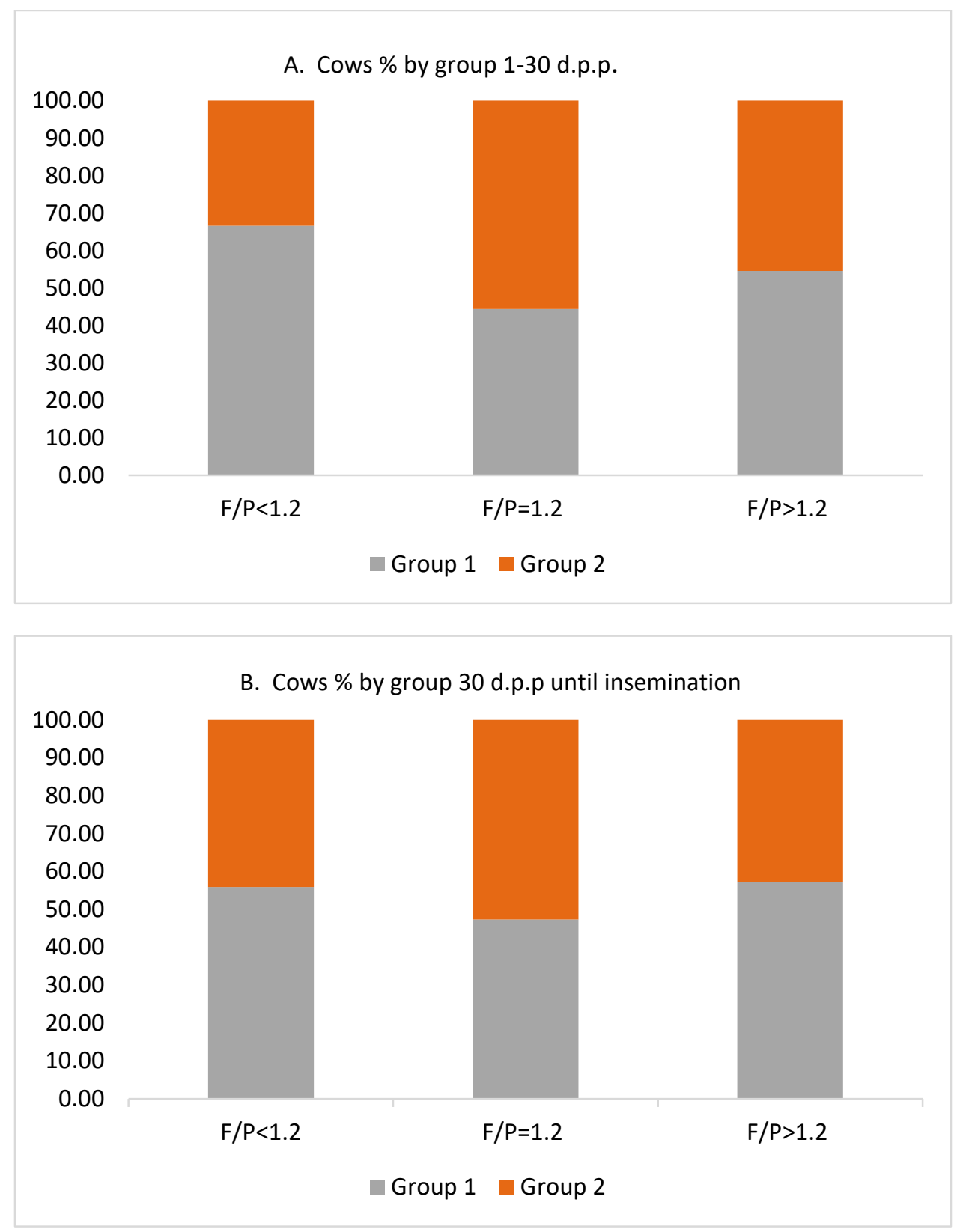

Figure 4. Relationship of milk fat to protein ratio with milk lactose level. (A). 1-30.p.p., (B). From 30 d.p.p. until insemination. Group 1-milk lactose $<4.70 \%$, Group 2-milk lactose $\geq 4.70 \%$. F/P-milk fat/protein ratio.

\subsection{The Relationship between the Level of Milk Lactose and Biomarkers from AMS}

The average reticulorumen $\mathrm{pH}$ of all cows was $6.42 \pm 0.002$, reticulorumen temperature$38.83 \pm 0.041{ }^{\circ} \mathrm{C}$, activity $-9.913 \pm 0.656 \mathrm{steps} /$ hour, and RT—441.14 $\pm 12.58 \mathrm{~min} / \mathrm{d}$.

Reticulorumen $\mathrm{pH}$ in group 2 was $02.1652 \%$ higher $(P<0.001)$, level of activity54.547 steps $/$ hour $\%$ higher $(P<0.001)$, and rumination time $-469.0786 \% \mathrm{~min} / \mathrm{d}$. longer, compared to cows of group 1 (Table 1).

Milk lactose highly positively correlated with reticulorumen $\mathrm{pH}$ and activity of cows $(P<0.01)$. 
Table 1. Indicators of reticulorumen, rumination time (RT) and activity of cows and their relationship with milk lactose.

\begin{tabular}{|c|c|c|c|c|c|}
\hline Group of Cows & Statistic & Reticulorumen $\mathrm{pH}$ & Reticulorumen $\mathrm{T}^{\circ} \mathrm{C}$ & $\begin{array}{l}\text { Rumination Time, } \\
\text { min/d. }\end{array}$ & $\begin{array}{c}\text { Activity of Cows, } \\
\text { Steps/Hour }\end{array}$ \\
\hline \multicolumn{6}{|c|}{ 1-30 d.p.p. } \\
\hline \multirow{2}{*}{1} & M & 6.34 & 38.84 & 467.40 & 8.39 \\
\hline & SE & 0.291 & 0.113 & 34.230 & 1.006 \\
\hline \multirow{2}{*}{2} & M & $6.50 * *$ & 38.82 & 421.33 & $12.96^{* *}$ \\
\hline & SE & 0.302 & 0.263 & 49.600 & 4.186 \\
\hline \multicolumn{2}{|c|}{ Correlation } & $0.762 *$ & 0.130 & -0.296 & $0.751 *$ \\
\hline \multicolumn{6}{|c|}{30 d.p.p.-until insemination } \\
\hline \multirow[b]{2}{*}{1} & M & 6.48 & 38.85 & 465.67 & 8.22 \\
\hline & SE & 0.039 & 0.088 & 13.951 & 0.515 \\
\hline \multirow{2}{*}{2} & M & 6.62 & $38.66^{* *}$ & 443.00 & 9.67 \\
\hline & SE & 0.001 & 0.002 & 10.157 & 0.001 \\
\hline \multicolumn{2}{|c|}{ Correlation } & $0.567^{*}$ & 0.176 & -0.223 & $0.753 *$ \\
\hline
\end{tabular}

$\mathrm{M}$ - mean; SE—standard of error of the mean; d.p.p.—days post partum; the difference between the groups is statistically significant, ${ }^{*} P<0.01,{ }^{* *} P<0.005$.

\subsection{Relationship between Milk Lactose and Cow Reproduction Success}

In the first group, $65.00 \%$ of cows did not become pregnant, and in the second group, only $6.67 \%$ did not become pregnant $(P<0.001)$

Lactose levels in cows' milk were positively associated with their reproductive success. We estimated that cows with the milk lactose level of $\geq 4.70 \%$ were 26 times more likely to have reproductive success than cows with milk lactose of $<4.70 \%(\mathrm{OR}=26.000, P=0.004)$. Data from binary logistic regression analysis are presented in Table 2.

Table 2. Relationship of milk lactose with pregnancy.

\begin{tabular}{ccccccc}
\hline Source & B & S.E. B & Wald $\chi^{\mathbf{2}}$ & df & P & OR \\
\hline Group & 3.258 & 1.136 & 8.221 & 1 & 0.004 & 26.000 \\
Constant & -3.877 & 1.397 & 7.707 & 1 & 0.006 & 0.021
\end{tabular}

$\mathrm{B}$-the unstandardized regression weight, S.E.-standard error for B, Wald $\chi^{2}$ - the Wald chi-square statistic, $\mathrm{df}$ - degrees of freedom, OR—odds ratio. Group 1 -milk lactose $<4.70 \%$, Group 2 -milk lactose $\geq 4.70 \%$.

\section{Discussion}

In the current study, we hypothesized that inline registered milk lactose can act as an indicator of health status and reproduction success in fresh dairy cows.

Lactose, EC and their combination together were the most accurate parameters for detection of mastitis in dairy farms equipped with in-line sensors. Clinical (CM) and subclinical (SCM) mastitis negatively influence the quality and quantity of milk and therefore they are of considerable economic concern for the dairy industry. Early detection of mastitis (especially SCM) can have an improvement on animal welfare and the quality of milk production and has the potential to increase economic gains [17]. According to the current study, we found that with increased concentration of lactose, the probability of mastitis decreases, confirmed with decreases in milk EC and SCC. The concentration of lactose has been reported to be influenced by high milk somatic cell counts (SCC). Berglund et al. [17] observed that an increase from 31,000-450,000 somatic cells mL-1 decreased the lactose concentration from $4.86-4.69 \%$. This was due to a reduction in lactose secretion [18] and loss of lactose to the blood vessels when the d permeability of the tight junction increased [19]. Substantial reductions in the lactose levels were correlated with the increase in SCC, as observed in the factor analysis, in which the lactose content had a contrary relationship with SCC [20]. Phenotypic and genetic correlations of $-0.774--0.227$ between the lactose content and SCS were estimated by Lindmark-Månsson et al. [21] and 
Miglior et al. [22], respectively. The increase in SCC, which indicates clinical and subclinical mastitis, decreases the lactose levels in milk, due to changes in the homeostasis of mammary glands [23], increasing the blood concentration of lactose [24]. Capuco et al. [25], as well as Schneeberger and Lynch [26], reported it to increase the blood concentration of lactose, which is an indicator of the integrity of the mammary epithelium [24,27]. According to Leitner et al. [28], blood lactose is increased in cases of subclinical mastitis and, in a more pronounced way, in clinical mastitis. However, in subclinical mastitis, the integrity of tight junctions is partly maintained. Leitner et al. [18] argued that the lower concentration of lactose in cows with intramammary infection was also related to the reduction in the secretion of lactose by further conversion of plasminogen to plasmin. Ebrahimie et al. [29] found that milk lactose concentrations decrease and SCC increases during clinical and subclinical mastitis. Few studies by other scientists show that lactose, SCC and milk electrical conductivity have been widely reported to be some of the most informative traits for mastitis diagnosis [30,31]. According to a study carried out by Costa et al. [32], mastitis genetically correlated with milk lactose yield.

The results in this study indicate that cows with a low lactose $(<4.70 \%)$ and milk F/P ratio in the interval $(<1 ;>2)$ reliably increased the risk of metabolic disorders (subclinical ketosis and acidosis). Toni et al. [33] also found that the F/P interval $(<1 ;>2)$ in milk is a valuable indicator of negative energy balance and lipo-mobilization in postpartum cows. Ganter et al. [34] stated that due to a negative energy balance at the beginning of lactation, the milk fat content increases, followed by a decrease in milk protein contents, which makes the $\mathrm{F} / \mathrm{P}$ ratio a good indicator in metabolic disorder detection.

We found that cows with a higher milk lactose concentration were more active (by $54.47 \%$ ) and were at less risk of subclinical acidosis (SARA) (indicated by $2.52 \%$ higher reticuloruminal $\mathrm{pH}$ and $9.86 \%$ longer rumination time). Antanaitis et al. [35] reported that cows with acidosis showed lower activity than healthy cows. According to Church [36], increased rumination time activates saliva production. Saliva consists of inorganic buffers that neutralize the organic acids produced during fermentation in the rumen [36,37]. According to other studies, the rumen content $\mathrm{pH}$, which is used to define SARA, is still a controversial issue [38]; however, in previous studies [39-41], a drop in rumen $\mathrm{pH}$ below 6 indicated the occurrence of SARA. Agreeing with Antanaitis et al. [42], cows affected by SARA have been shown to have reduced rumination time.

Data from this study also confirmed that higher levels of lactose in cows' milk are associated with a lower risk of mastitis. In other studies, the heritability coefficient for milk lactose $\left(h^{2}=0.279\right)$ and a negative genetic correlation $\left(r_{g}=-0.43 ; p<0.01\right)$ with milk somatic cells [43] were determined.

Lactose is a vital osmotic component of milk and is a major driver of water secretion into milk from the bloodstream. Thus, a lower lactose content results in a smaller volume of milk produced [31].

According to our results, evaluating the relationship between milk lactose concentration and cow reproduction success, we found that cows with higher milk lactose concentration $(\geq 4.70 \%)$ had a better probability for pregnancy $(65.00 \%)$ than cows with lower milk lactose concentrations $(<4.70 \%)$. Reksen et al. [10] found that second-parity lactation cows with higher milk lactose concentration in the first 8 weeks after calving had an earlier luteal response. Comparing the relationship between milk lactose concentration and cow energy balance and its use to assess cow reproduction success, the results of our study are consistent with those of Buckley et al. [9]. Their results state that the amount of lactose in milk, which correlates with the amount of glucose in the blood, can be used not only to assess the energy balance of cows but also their reproductive success.

\section{Conclusions}

Based on our results, a conclusion can be made that inline registered milk lactose concentration can be an indicator for the health status of dairy cows. Cows with a higher lactose concentration $(\geq 4.70 \%)$ were registered as more active $(54.47 \%)$ and were at less risk 
of mastitis (as indicated by lower milk EC and SCC) and metabolic disorders, determined by milk F/P. Low levels of lactose can indicate mastitis (milk SCC $\geq 100$ thousand $/ \mathrm{mL}$ ) and metabolic disorders (subclinical ketosis, subclinical acidosis), described by milk F/P. Cows with higher milk lactose concentration have a higher possibility of successful conception.

Author Contributions: M.T.: management of the whole study; V.J.: algorithm and software development, design and setup of field experiments, data collection and analysis; D.M.: setup of the field experiment and data collection, management and selection of the experimental group of animals; R.A.: research consultancy; A.R.: building of field experiment, data collection and analysis; M.U.: design of field experiment and data analysis and collection; and W.B.: major support in processing of data in the study. The manuscript was written by M.T. and revised by all co-authors. All authors have read and agreed to the published version of the manuscript.

Funding: This research was not externally funded.

Institutional Review Board Statement: The study was conducted according to the guidelines of the Declaration of Helsinki, and approved by Ethics Committee (The study approval number is PK016965, 2017.06.06).

Informed Consent Statement: Informed consent was obtained from all subjects involved in the study.

Data Availability Statement: The data presented in this study are available within the article.

Conflicts of Interest: The authors declare no conflict of interest.

\section{References}

1. Berckmans, D. Precision livestock farming technologies for welfare management in intensive livestock systems. Rev. Sci. Tech. Off. Int. Epiz. 2014, 33, 189-196. [CrossRef] [PubMed]

2. Jacobs, J.A.; Siegford, J.M. Invited review: The impact of automatic milking systems on dairy cow management, behavior, health, and welfare. J. Dairy Sci. 2012, 95, 2227-2247. [CrossRef] [PubMed]

3. Spahr, S.L.; Maltz, E. Herd management for robot milk-ing. Comp. Electron. Agric. 1997, 17, 53-62. [CrossRef]

4. Halachmi, I.; Guarino, M. Editorial: Precision livestock farming: A "per animal" approach using advanced monitoring technologies. Anim. Consortc. 2016, 10, 1482-1483. [CrossRef] [PubMed]

5. Halachmi, I. Designing the automatic milking farm in a hot climate. J. Dairy Sci. 2004, 87, 764-775. [CrossRef]

6. Costa, A.; Egger-Danner, C.; Mészáros, G.; Fuerst, C.; Penasa, M.; Sölkner, J.; Fuerst-Waltl, B. Genetic associations of lactose and its ratios to other milk solids with health traits in Austrian Fleckvieh cows. J. Dairy Sci. 2019, 102, 4238-4248. [CrossRef] [PubMed]

7. Miglior, F.; Sewalem, A.; Jamrozik, J.; Lefebvre, D.M.; Moore, R.K. Analysis of Milk Urea Nitrogen and Lactose and Their Effect on Longevity in Canadian Dairy Cattle. J. Dairy Sci. 2006, 89, 4886-4894. [CrossRef]

8. Francisco, C.C.; Spicer, L.J.; Payton, M.E. Predicting cholesterol, progesterone, and days to ovulation using postpartum metabolic and endocrine measures. J. Dairy Sci. 2003, 86, 2852-2863. [CrossRef]

9. Buckley, F.; O'Sullivan, K.; Mee, J.F.; Evans, R.D.; Dillon, P. Relationships among milk yield, body condition, cow weight, and reproduction in spring-calved Holstein-Friesians. J. Dairy Sci. 2003, 86, 2308-2319. [CrossRef]

10. Reksen, O.; Havrevoll, Ø.; Gröhn, Y.T.; Bolstad, T.; Waldmann, A.; Ropstad, E. Relationships among body condition score, milk constituents, and postpartum luteal function in Norwegian dairy cows. J. Dairy Sci. 2002, 85, 1406-1415. [CrossRef]

11. Steen, A.; Østerås, O.; Grønstøl, H. Evaluation of additional acetone and urea analyses, and of the fat-lactose-quotient in cow milk samples in the herd recording system in Norway. J. Vet. Med. A 1996, 43, 181-191. [CrossRef] [PubMed]

12. Reist, M.; Erdin, D.; von Euw, D.; Tschuemperlin, K.; Leuenberger, H.; Chilliard, Y.; Hammon, H.M.; Morel, C.; Philipona, C.; Zbinden, Y.; et al. Estimation of energy balance at the individual and herd level using blood and milk traits in high-yielding dairy cows. J. Dairy Sci. 2002, 85, 3314-3327. [CrossRef]

13. Pyöräla, S. Indicators of inflammation in the diagnosis of mastitis. Vet. Res. 2003, 34, 565-578. [CrossRef]

14. Leitner, G.; Lavi, Y.; Merin, U.; Lemberskiy-Kuzin, L.; Katz, G. Online evaluation of milk quality according to coagulation properties for its optimal distribution for industrial applications. J. Dairy Sci. 2011, 94, 2923-2932. [CrossRef] [PubMed]

15. Rigout, S.; Lemosquet, S.; van Eys, J.E.; Blum, J.W.; Rulquin, H. Duodenal glucose increases glucose fluxes and lactose synthesis in grass silage-fed dairy cows. J. Dairy Sci. 2002, 85, 595-606. [CrossRef]

16. Qiao, F.; Trout, D.R.; Xiao, C.; Cant, J.P. Kinetics of glucose transport and sequestration in lactating bovine mammary glands measured in vivo with a paired indicator/nutrient dilution technique. J. Applied Phys. 2005, 99, 799-806. [CrossRef]

17. Berglund, I.; Pettersson, G.; Ostensson, K.; Svennersten-Sjaunja, K. Quarter milking for improved detection of increased SCC. Rep. Dom. Anim. Malden. 2007, 42, 427-432. [CrossRef]

18. Leitner, G.; Merin, U.; Lavi, Y.; Egber, A.; Silanikove, N. Aetiology of intramammary infection and its effect on milk composition in goat flocks. J. Dairy Res. 2007, 74, 186-193. [CrossRef] 
19. Moussaoui, F.; Vangroenweghe, F.; Haddadi, K.; Le Roux, Y.; Laurent, F.; Duchateau, L.; Burvenich, C. Proteolysis in milk during experimental Escherichia coli mastitis. J. Dairy Sci. 2004, 87, 2923-2931. [CrossRef]

20. Alessio, M.; Regina, D.; André, T.N.; Pedro, V.J.; Ildemar, B.P.; José, M.D.; Aline, K.D.; Claudineli, G.S. Multivariate analysis of lactose content in milk of Holstein and Jersey cows. Ciênci. Agrár. 2016, 37, 2641-2652. [CrossRef]

21. Lindmark-Mansson, H.; Branning, C.; Alden, G.; Paulsson, M. Relationship between somatic cell count individual leukocyte populations and milk components in bovine udder quarter milk. Inter. Dairy J. 2006, 16, 717-727. [CrossRef]

22. Miglior, F.; Sewalem, A.; Jamprozik, J.; Bohmanova, J.; Lefebvre, D.M.; Moore, R.K. Genetic analysis of milk urea nitrogen and lactose and their relationships with other production traits in Canadian Holstein cattle. J. Dairy Sci. 2007, 90, 2468-2479. [CrossRef] [PubMed]

23. Pessora, R.B.; Blagitz, M.G.; Batista, C.F.; Santos, B.P.; Parra, A.C.; Souza, F.N.; Della Libera, A.M.M.P. Polymorphonuclear leukocytes $\mathrm{CH} 138+$ apoptosis evaluation in milk with high and low somatic cell count-preliminary data. Arq. Bras. Med. Vet. Zootec. 2012, 64, 533-539.

24. Ben Chedly, H.; Lacasse, P.; Marnet, P.; Wiart-Letort, S.; Finot, L.; Boutinaud, M. Cell junction disruption after 36 h milk accumulation was associated with changes in mammary secretory tissue activity and dynamics in lactating dairy goats. J. Phys. Pharm. Off. J. Pol. Physiol. Soc. 2009, 60, 105-111.

25. Schneeberger, E.E.; Lynch, R.D. Structure, function and regulation of cellular tight junctions. Americ. J. Phys. 1992, $262,647-661$. [CrossRef]

26. Capuco, A.V.; Ellis, S.E.; Hale, S.A.; Long, E.; Erdman, R.A.; Zhao, X.; Paape, M.J. Lactation persistency: Insights from mammary cell proliferation studies. J. Anim. Sci. 2003, 81, 18-31. [CrossRef]

27. Stelwagen, K.; Davis, S.R.; Farr, V.C.; Eichler, S.J.; Politis, I. Effect of once daily milking and concurrent somatotropin on mammary tight junction permeability and yield of cows. J. Dairy Sci. 1994, 77, 2994-3001. [CrossRef]

28. Leitner, G.; Chaffer, M.; Shamay, A.; Shapiro, F.; Merin, U.; Ezra, E.; Saran, A.; Silanikove, N. Changes in milk composition as affected by subclinical mastitis in sheep. J. Dairy Sci. 2004, 87, 46-52. [CrossRef]

29. Ebrahimie, E.; Ebrahimi, F.; Ebrahimi, M.; Tomlinson, T.; Petrovski, K.R. A large-scale study of indicators of sub-clinical mastitis in dairy cattle by attribute weighting analysis of milk composition features: Highlighting the predictive power of lactose and electrical conductivity. J. Dairy Res. 2018, 85, 193-200. [CrossRef]

30. Geary, U.; Lopez-Villalobos, N.; O’Brien, B.; Garrick, D.J.; Shalloo, L. Estimating the impact of somatic cell count on the value of milk utilising parameters obtained from the published literature. J. Dairy Res. 2014, 81, 223-232. [CrossRef]

31. Vilas Boas, D.F.; Vercesi Filho, A.E.; Pereira, M.A.; Roma Junior, L.C.; El Faro, L. Association between electrical conductivity and milk production traits in Dairy Gyr cows. J. Appl. Anim. Res. 2017, 45, 227-233. [CrossRef]

32. Costa, A.; Lopez-Villalobos, N.; Sneddon, N.W.; Shalloo, L.; Franzoi, M.; De Marchi, M.; Penasa, M. Invited review: Milk lactose-Current status and future challenges in dairy cattle. J. Dairy Sci. 2019, 102, 5883-5898. [CrossRef] [PubMed]

33. Toni, F.; Vincenti, L.; Grigoletto, L.; Ricci, A.; Schukken, Y.H. Early lactation ratio of fat and protein percentage in milk is associated with health, milk production, and survival. J. Dairy Sci. 2011, 94, 1772-1783. [CrossRef] [PubMed]

34. Gantner, V.; Bobic, T.; Potocnik, K. Prevalence of metabolic disorders and effect on subsequent daily milk quantity and quality in Holstein cows. Arch. Anim. Breed. 2016, 59, 381-386. [CrossRef]

35. Antanaitis, R.; Žilaitis, V.; Kučinskas, K.; Juozaitienè, V.; Leonauskaitè, K. Changes in cow activity, milk yield, and milk conductivity before clinical diagnosis of ketosis, and acidosis. Vet. Med. Zoot. 2015, 70, 1392-2130.

36. Church, D.C. Salivary function and production. In The Ruminant Animal, Digestive Physiology and Nutrition; Prentice Hall: Englewood Cliffs, NJ, USA, 1988; pp. 117-124.

37. Plaiziera, J.C.; Krausea, D.O.; Gozhob, G.N.; McBridec, B.W. Subacute ruminal acidosis in dairy cows: The physiological causes, incidence and consequences. Vet. J. 2008, 176, 21-31. [CrossRef]

38. Gozho, G.N.; Plaizier, J.C.; Krause, D.O.; Kennedy, A.D.; Wittenberg, K.M. Subacute Ruminal Acidosis Induces Ruminal Lipopolysaccharide Endotoxin Release and Triggers an Inflammatory Response. J. Dairy Sci. 2005, 88, 1399-1403. [CrossRef]

39. Hibbard, B.; Peters, J.P.; Chester, S.T.; Robinson, J.A.; Kotarski, S.; Croom, W.J.; Hagler, W.M. The effect of slaframine on salivary output and subacute and acute acidosis in growing beef steers. J. Anim. Sci. 1995, 73, 516-525. [CrossRef]

40. Kriehbiel, C.R.; Britton, R.A.; Harmon, D.L.; Wester, T.J.; Stock, R.A. The effects of ruminal acidosis on volatile fatty acid absorption and plasma activities of pancreatic enzymes in lambs. J. Anim. Sci. 1995, 73, 3111-3121. [CrossRef]

41. Beauchemin, K.A.; Yang, W.Z.; Rode, L.M. Effects of barley grain processing on the site and extent of digestion in beef. J. Anim. Sci. 2001, 79, 1925-1936. [CrossRef]

42. Antanaitis, R.; Juozaitienè, V.; Malašauskienè, D.; Televičius, M. Can rumination time and some blood biochemical parameters be used as biomarkers for the diagnosis of subclinical acidosis and subclinical ketosis. Vet. Anim. Sci. 2019, 8, 100077. [CrossRef] [PubMed]

43. Shimkiene, A.; Juozaitiene, V.; Juozaitis, A.; Shimkus, A.; Zilaitis, V.; Urbonavicius, A. Relationship between lactose content in cow's milk with selection attributes and heritability. Veterinarija ir zootechnika. Vet. Med. Zoot. 2009, 45, 81-86. 